\title{
The Geography of Politics: A Case for the Political Redistricting of Adamawa State, Nigeria
}

\author{
AbdullahiLimanTukur ,Mohammed MahmudBarde \\ Department of Geography,School of Environmental Sciences,ModibboAdama University of Technology \\ Yola,Adamawa State Nigeria
}

\begin{abstract}
This paper examines current political representations in Adamawa State in the light of democratic principles of fairness, justice and equity to propose a redistricting of the state with a view to redressing imbalances and deviations from standard practices and the law. It is argued that the current situation where an area is being represented by six members in the state assembly and one member at the federal house of representative on the one hand and another area represented by two members in the state assembly and one member at the federal house of representative on the other hand is not only absurd, lopsided and illogical but also cannot be said to be democratic. This situation has created and sustained feelings of marginalization and deprivation. A redistricting that redresses such imbalances and inequities is proposed using standard criteria, within a Geographic Information System environment, to achieve democratic imperatives of fairness and justice.
\end{abstract}

Key Words: Redistricting Adamawa, democratic fairness, justice

\section{Introduction}

Early on return to civil rule in Nigeria in 1999 notable international agencies concerned with democracy and development; such as the Commonwealths Office, the International Foundation for Electoral Systems (IFES) and the United Nations Electoral Assistance Division (UNEAD), were approached to help review Nigeria's electoral arrangement with a view to achieving a realistic electoral reform. The invited agencies worked assiduously and by July 2003 submitted a report, to the Independent National Electoral Commission (INEC), which among other things recommended that"a new delimitation exercise for federal and state assembly constituencies will need to be completed before the 2007 elections. The demarcation of boundaries, according to the law, should be based on the 1991 census or the latest national census: with each constituency, as far as possible, containing the same number of inhabitants" $\{1\}$. This and many other recommendations were anchored on the imperatives that fair elections, and by extension representations, required constituencies to have relativelyequal voter population such that; as rightly agued by $\operatorname{Horn}\{2\}\{3\}$, democracy's principle of fairness and associated idea of citizens being equal truly implies that everyone's vote carries an equal value. More than ten years since the submission of the Nigeria Electoral Review Report, the INEC Chairman (AttahiruJega) reechoed the need to delineate constituencies at a national retreat on constituency delimitation held in Enugu in May 2013\{4\}; noting that "the current delimitation structure is a product of the defunct NECON in 1996 under a military regime using the 1991 census data". It was also noted that the existing districts are among many other challenges characterized by malapportionment, deviation from constitutional guidelines and other imbalances. The INEC Chairman, therefore, assured that the commission was "determined to partner with all stakeholders to execute a transparent, rational and impartial delimitation of electoral constituencies". Of course, any one conversant with existing political units of representation from the ward level (where local councilors are elected) to state and national assembly seats, knows that settlements, communities and interest groups do not have equal access, freedom and security to freely vote as they will ordinarily want to do as voting centers/units and collation venues were deliberately sited to favor/disadvantage certain interest. This has created not only political inequality but also willfully, deliberately and in some cases perpetually created permanent losers. Thus, any attempt at reapportionment that is meant to enhance fairness and minimize the effect of gerrymandering will develop the essential components of democracy and safeguard balance of rights and responsibilities. Thus, as emphasized by Morrison $\{5\}$, justice and fairness through redistricting are a necessary part of practical politics, survival, sustainability and the pursuit of informed selfinterest. This is very much in line with Saunders' $\{6\}$ argument that democracy can only be acceptable to all if "it gives each at least a chance of getting at least some of what they want." That can only be achieved through fair, impartial and transparent districting.

The current structure that assigned seats in the State Assemblies and House of Representatives among states based on population account may appear relatively well balanced but detailed analysis will quickly reveal serious inequality particularly within states as opposed to between states. In the northeastern geo-political unit 
of Nigeria, for instance, Table 1 shows a fairly balanced distribution of seats among states. The geo-political unit has a total landmass of 292,610 square kilometers, a population of 18,971,965 (2006 census) \{7\}, 112 local government areas, 1210 wards, 48 members in the national assembly and 156 members in the states' assemblies.

Table 1: The configuration of the North-eastern geopolitical states

\begin{tabular}{|c|c|c|c|c|c|c|}
\hline $\begin{array}{l}\text { Serial } \\
\text { No. }\end{array}$ & States & \% Landmass & $\%$ Population & $\%$ Wards & $\begin{array}{l}\% \text { members in } \\
\text { State Assembly }\end{array}$ & $\begin{array}{c}\% \text { members in } \\
\text { National } \\
\text { Assembly }\end{array}$ \\
\hline 1 & Adamawa & 12.61 & 16.69 & 18.67 & 16.00 & 16.66 \\
\hline 2 & Bauchi & 22.07 & 24.64 & 17.52 & 19.87 & 25.00 \\
\hline 3 & Borno & 24.31 & 21.88 & 25.78 & 17.90 & 20.83 \\
\hline 4 & Gombe & 6.41 & 12.40 & 9.42 & 15.38 & 12.50 \\
\hline 5 & Taraba & 19.11 & 12.13 & 13.88 & 15.38 & 12.50 \\
\hline 6 & Yobe & 15.57 & 12.23 & 14.71 & 15.38 & 12.50 \\
\hline
\end{tabular}

Source:Computed from 2006 Census Data (FGN) $\{6\}$ and Various States' Dairies and also

www.nigerianmuse.com/.../inec-distribution-of-senatorial-districts-federal-a.. $\{7\}$

A close look at columns four, six and seven reveal a very strong association, suggesting population count was the major if not the only variable considered in apportionment of seats to states. Cursory observation and analysis of within state districting show glaring inequality in representation taking into cognizance population and landmass among many other variables of significance in apportionment. If one voter's vote in an "election is to be worth as much as another's" as aptly contended by Crocker $\{8\}$ should be the foundation of democratic fairness and justice, what obtains in many Nigerian states and specifically Adamawa State cannot qualify as fair or just. Thus, the aim of this paper to examine the current structure and propose a realistic reapportionment based on international best practices in political districting. These, it is hoped, can be achieved by examining the current relative representations at the State Assembly, House of Representatives and the Senate in line with standard criteria and international best practices in redistricting.

\section{Adamawa State}

Adamawa, as already noted, is one of the six states forming the northeast geo-political zone of Nigeria. It lies between latitude $7^{0}$ and $11^{\circ} \mathrm{N}$ of the equator and between longitude $11^{0}$ and $14^{\circ} \mathrm{E}$ of the Greenwich meridian. The state covers a land area of about $39,972 \mathrm{~km}^{2}$ with a population of 3,168,101 according to the 2006 census. Adamawa State as it is today was carved out of the defunct Gongola State on August $27^{\text {th }} 1991$. Gongola State was itself carved out of the then North-Eastern State in February 1976. Yola, the capital city of Adamawa State, was founded by ModibboAdama in 1841 and had served as the headquarters of the pre-colonial Emirate of Fombina. Yola had also served as the seat of the then Adamawa Province from the colonial era to 1976. Since the creation of Gongola, and subsequently Adamawa State, Yola (and its twin settlement, Jimeta, 6km due north) became the capital of both the state and local governments of Yola North and South.

The River Benue divides Adamawa State into almost two equal halves; each half having varying types and extent of landforms, one of which is valleys/troughs; such as the River Benue and its tributaries like Rivers Gongola, Song and Kilange on the northern flank and Rivers Ini, Belwa and Faro on the southern bank (see Fig. 1). There are also lowlands lying generally immediate to the valleys and troughs especially in the central part of the state and upland plains such as areas immediate to or lying at the foot of hills and mountains. The upland plains form the largest landform type and also the most heavily dissected by numerous sharp and steep-sided streams of well-developed dendritic pattern. Other landform types are the hills/mountain ranges that constitute the most striking features in the state, generally appearing as grouped hills and mostly trending south to north particularly along the eastern borderlands of Nigeria and Cameroon. The Atlantika, Shebshi-Jangani Mountains in the southern part and the Muduru, Maiha-Gela and Mandara granitic mountain ranges in the north are the most prominent. $\{9\}$

In terms of political and administrative set-up Adamawa State is made up of twenty-one (21) local government areas and thirty-seven development areas. There are also eight (8) first class traditional rulers with one hundred and four (104) traditional administrative districts. Adamawa State also has 2,609 polling units spread over 226 electoral wards, twenty-five State Assembly Constituencies, eight Federal (House of Representatives) constituencies and, like any state, three Senatorial Districts. Adamawa is diverse not only in physical features but also culturally as depicted by the ways of life of the over 60 language and over 40 ethnic groups inhabiting the state. Thus, physically, Adamawa State is one of the most rugged and punctuated landscape and also, culturally, the most diverse/heterogeneous of all the states in the northeast geopolitical zone. In such a state of complex landscape and varied language/ethnic groups various factors must be taken into consideration to achieve equity and justice in political and democratic representations. 


\section{Methodology}

To satisfy the rudiments of democratic fairness and justice, and also stay free of partisan gerrymandering, non-discriminatory variables of physical characteristics and demographic data as provided by an independent government agency were impartially and transparently used.Thus, various data types and sources were integrated to define and map political district under strict principles of neutrality. The following factors and characteristics within each local government area and existing districts at various levels were critically and objectively analyzed:

i) Population and settlement patterns

ii) Geographical area/features including ease of transportation and communication

iii) Administrative and historical factors

iv) Social and cultural peculiarities

A Geographic Information System (GIS) environment $\{3\}$ is certainly of relevance and easily lends itself in this exercise as computation and mapping tasks can easily and accurately be achieved within reasonable time and cost.

\subsection{GIS Hard and Software}

A number of GIS hard and software were employed and they include; a laptop Computer (with high speed processor; Pentium ${ }^{\circledR}$ dual-core CPU T4200 @ $2.00 \mathrm{GHz}$ with Random Access Memory (RAM) of 4.00GB and 500GB Hard Disk Drive "HDD"), HP Scanjet G2710 scanner, and a HP desk jet 930c Photo printer. The Software components include Environmental System and Research Institute's (ESRI) ArcGIS version10.1 with the embedded components such as ArcMap; used in geo-referencing digitization of geospatial data and data editing for the creation of feature class elements. Component software, ArcCatalog, where folders and files were created for storing geodatabase and management of feature classes and layers was also used. The major input data were Adamawa State map at a scale of 1:75,000 of 1999 obtained from the Department of Geography, ModibboAdama University of Technology Yola and population data of 2006 from the National Population Commission, Nigeria.

\subsection{Data Scanning and Processing}

The HP Scanjet G2710 was used for scanning of spatial data (Adamawa state map), saved as 'Jpeg' files for importation to the ArcMap environment for an on screen geo-referencing and digitization. The edit session enabled the creation of geodatabase that produce a meaningful and comprehensive digital map of Adamawa.

ArcCatalog was where the Adamawa Geodatabase folder was created and the feature class files were created with the appropriate coordinate system and stored under the geodatabase for Adamawa. A specific feature class was selected as a target layer during edit session and map features were edited and saved as spatial layers in the table of content.

\subsection{Delineation of Electoral Units Boundaries}

The digital map of Adamawa state gives a continuous spatial data that serve as a base map, on which population, area and other thematic data or information were manipulated and displayed. Political units' boundaries for this study were created in an ArcMap environment. The "cut polygon" tool was used to create the political or electoral district from the Adamawa polygon on to the existing and proposed target layers, usually known as feature classes. Thus, three pairs of layers representing the existing and proposed constituencies and the population and area percentages were generated in columns attribute tables.In all cases of units (districts) of representation geographical contiguity was ensured and whole local government area was considered in creating federal constituencies and senatorial districts while whole wards were considered in stat constituencies.

\subsection{Statistical analysis}

The statistical analysis such as percentages of landmass and population were directly derived from buffered areas of each constituency/district and bar graphs were used for visual presentation of information.

\section{Analysis and Discussions}

In the current apportionment of seats in the state, federal house of representatives and the senate, Adamawa has twenty-five, eight and three representatives respectively; coded SC/25/AD to SC/49/AD for the state constituencies, FC009/AD to FC016/AD for the federal and SD004/AD to SD006/AD for the senatorial district by the INEC. Table 2 provides details in terms of landmass, population, wards and number of state constituencies within each of the eight Federal Constituencies. 
The Geography of Politics: A Case for the Political Redistricting of Adamawa State, Nigeria

Table 2: Composition of Federal Constituencies

\begin{tabular}{|c|c|c|c|c|c|}
\hline S/No. & Federal Constituency & Landmass $\left(\mathrm{Km}^{2}\right)$ & Population & No. of Wards & $\begin{array}{l}\text { No. of State } \\
\text { Constituencies }\end{array}$ \\
\hline 1. & $\begin{array}{l}\text { Demsa } \\
\text { Numan } \\
\text { Lamurde (FC009/AD) }\end{array}$ & $\begin{array}{l}1900.31 \\
940.00 \\
1174.69 \\
\mathbf{4 , 0 1 5 . 0 0}(10.04 \%) \\
\end{array}$ & $\begin{array}{l}178,407 \\
91,549 \\
111,254 \\
\mathbf{3 8 1 , 2 1 0}(11.99 \%) \\
\end{array}$ & $\begin{array}{l}10 \\
10 \\
10 \\
\mathbf{3 0}(13.27 \%) \\
\end{array}$ & $\begin{array}{l}1 \\
1 \\
1 \\
\mathbf{3}(12 \%) \\
\end{array}$ \\
\hline 2. & $\begin{array}{l}\text { Fufore } \\
\text { Song (FC10/AD) }\end{array}$ & $\begin{array}{l}5169.32 \\
4325.00 \\
\mathbf{9 , 4 9 4 . 3 2}(23.75 \%)\end{array}$ & $\begin{array}{l}209,460 \\
195,188 \\
\mathbf{4 0 4 , 6 4 8}(12.73 \%)\end{array}$ & $\begin{array}{l}11 \\
11 \\
\mathbf{2 2}(9.73 \%)\end{array}$ & $\begin{array}{l}2 \\
1 \\
\mathbf{3}(12 \%)\end{array}$ \\
\hline 3. & $\begin{array}{l}\text { Mayo-Belwa } \\
\text { Ganye } \\
\text { Jada } \\
\text { Toungo (FC011/AD) }\end{array}$ & $\begin{array}{l}1702.45 \\
2011.47 \\
2926.11 \\
5665.37 \\
\mathbf{1 2 , 3 0 5 . 4 0}(30.78 \%)\end{array}$ & $\begin{array}{l}152,803 \\
169,948 \\
168,445 \\
52,171 \\
\mathbf{5 4 3 , 3 6 7}(17.09 \%)\end{array}$ & $\begin{array}{l}12 \\
10 \\
11 \\
10 \\
\mathbf{4 3}(19.02 \%)\end{array}$ & $\begin{array}{l}2 \\
1 \\
2 \\
1 \\
6(24 \%)\end{array}$ \\
\hline 4. & $\begin{array}{l}\text { Gombi } \\
\text { Hong (FC012/AD) }\end{array}$ & $\begin{array}{l}1953.50 \\
2753.20 \\
\mathbf{4 , 7 0 6 . 7 0}(11.77 \%) \\
\end{array}$ & $\begin{array}{l}147,787 \\
169,183 \\
\mathbf{3 1 6 , 9 7 0}(9.97 \%) \\
\end{array}$ & $\begin{array}{l}10 \\
11 \\
\mathbf{2 1}(9.29 \%) \\
\end{array}$ & $\begin{array}{l}1 \\
2 \\
\mathbf{3}(12 \%)\end{array}$ \\
\hline 5. & $\begin{array}{l}\text { Guyuk } \\
\text { Shelleng (FC013/AD) }\end{array}$ & $\begin{array}{l}791.54 \\
1572.48 \\
\mathbf{2 , 3 6 4 . 0 2}(5.91 \%) \\
\end{array}$ & $\begin{array}{l}176,505 \\
148,490 \\
\mathbf{3 2 4 , 9 9 5}(10.22 \%) \\
\end{array}$ & $\begin{array}{l}11 \\
10 \\
\mathbf{2 1}(9.29 \%) \\
\end{array}$ & $\begin{array}{l}1 \\
1 \\
\mathbf{2}(8 \%)\end{array}$ \\
\hline 6. & $\begin{array}{l}\text { Madagali } \\
\text { Michika (FC014/AD) }\end{array}$ & $\begin{array}{l}976.10 \\
1080.05 \\
\mathbf{2 , 0 5 6 . 1 5}(5.14 \%) \\
\end{array}$ & $\begin{array}{l}135,142 \\
155,238 \\
\mathbf{2 9 0 , 3 8 0}(9.13 \%) \\
\end{array}$ & $\begin{array}{l}10 \\
16 \\
\mathbf{2 6}(11.50 \%) \\
\end{array}$ & $\begin{array}{l}1 \\
1 \\
2(8 \%) \\
\end{array}$ \\
\hline 7. & $\begin{array}{l}\text { Maiha } \\
\text { Mubi North } \\
\text { Mubi South (FC015/AD) }\end{array}$ & $\begin{array}{l}1385.00 \\
924.32 \\
517.99 \\
\mathbf{2 , 8 2 7 . 3 1}(7.07 \%) \\
\end{array}$ & $\begin{array}{l}110,175 \\
151,515 \\
129,956 \\
\mathbf{3 9 1 , 6 4 6}(12.32 \%) \\
\end{array}$ & $\begin{array}{l}10 \\
11 \\
10 \\
\mathbf{3 1}(13.71 \%) \\
\end{array}$ & $\begin{array}{l}1 \\
1 \\
1 \\
\mathbf{3}(12 \%) \\
\end{array}$ \\
\hline 8. & $\begin{array}{l}\text { Yola North } \\
\text { Yola South } \\
\text { Girei (FC016/AD) }\end{array}$ & $\begin{array}{l}111.85 \\
719.00 \\
1151.64 \\
\mathbf{1 , 9 8 2 . 4 9}(4.96 \%) \\
\end{array}$ & $\begin{array}{l}199,674 \\
196,197 \\
129,855 \\
\mathbf{5 2 5 , 7 2 6}(16.54 \%) \\
\end{array}$ & $\begin{array}{l}11 \\
11 \\
10 \\
\mathbf{3 2}(14.15 \%) \\
\end{array}$ & $\begin{array}{l}1 \\
1 \\
1 \\
\mathbf{3}(12 \%) \\
\end{array}$ \\
\hline Total & 8 & 39,972.30 & $3,178,950$ & 226 & 25 \\
\hline
\end{tabular}

Source: Musa and Tukur (2008), FGN (2009) and www.nigerianmuse.com/.../inec-distribution-of-senatorialdistricts-federal-a $\{9\}$

A close analysis of Table 2 brings to the fore the imbalances mentioned by Jega (2003) at the Enugu national retreat on constituency delimitation as earlier noted. The lack of associating of wards creation to population and landmass, as is the case with the apportionment of seats for the state and federal constituencies between states, led to a situation where the minimum of ten wards per LGA has no systematic progression in order to determine the maximum. Thus, it could not be explained how, for instance Michika LGA the $11^{\text {th }}$ in population and $14^{\text {th }}$ in landmass came to have 16 wards; six wards more than Toungo the largest LGA in terms of landmass and five wards more than Fufore the second largest and the highest in population. The most glaring of the imbalances in the current apportionment is the case where in one extreme a federal constituency has six state constituencies; that is six members in the state assembly, and in another only two state constituencies or two members in the state assembly represents a federal constituency. Thus, an area being represented by one member at the House of Representatives is as large as $12,305 \mathrm{~km}^{2}$ with over half-a-million population while another is just $2,000 \mathrm{~km}^{2}$ with a population of less than 300,000 (see Figs. 2 \& 3). Similarly, how some LGAs come to have two state constituencies could not also be explained in terms of population and/or landmass though the geography (shape, features that impede transportation/communication) cultural diversity and historical peculiarities of such LGAs may provide justification.

If the state and federal constituencies are not balanced, fair and equitable, the Senatorial Districts are by far the most imbalanced and disproportionate. The Northern Senatorial District (SD004/AD) is made up of five LGAs with a total landmass of less than $5000 \mathrm{Km} 2(12.72 \%$ of the state's landmass) and a population of only 682,026 (21.45\%); the Southern (SD005/AD) and Central (SD006/AD) have $46.74 \%$ and $40.49 \%$ of landmass and correspondingly $39.31 \%$ and $39.31 \%$ of population respectively. In terms of the number of LGAs making up each senatorial district, the Northern has five while the Southern and Central has nine and seven respectively. Hence, with this structure $44 \%$ of the state constituencies are in the southern district, $36 \%$ in the central and $20 \%$ in the northern districts (see Fig. 4).

From the foregoing it is clear that a well-adjusted and equitable redistricting is not only desirable but also necessary to ensure that democracy is just, fair and truly representative $\{10\}\{11\}$. Taking the existing structure into consideration within the context of the four variables outlined under the methodology revealed the need for the apportionment of more seats to the state both for the state and federal representation and realignment of the senatorial districts. Thus, for equity and fair representation five more seats for the state and two 
more for the federal constituencies may be ideal and defensible. For the state constituency, the additional five seats should be apportioned, one each, to Demsa, Ganye, Michika, Song and Yola South LGAs (see Fig. 5).

Table3 Proposed LGAs for Additional State Constituencies

\begin{tabular}{|c|c|c|c|c|}
\hline S/No. & LGA & Landmass $\left(\mathrm{Km}^{2}\right)$ & Population (2006) & Compelling Reason \\
\hline 1. & Demsa & $1900.31\left(8^{\text {th }}\right)$ & $178,407\left(5^{\text {th }}\right)$ & $\begin{array}{l}\text { Large population of diverse cultural (language) } \\
\text { background under two First Class rulers, difficult } \\
\text { terrain punctuated by the River Benue and several } \\
\text { other rivers; transportation and communication very } \\
\text { difficult. }\end{array}$ \\
\hline 2. & Ganye & $2011.47\left(6^{\text {th }}\right)$ & $169,948\left(7^{\text {th }}\right)$ & $\begin{array}{l}\text { Relatively large and difficult terrain including } \\
\text { mountain ranges, large population under seven } \\
\text { traditional administrative districts with long } \\
\text { historical rivalry and animosity }\end{array}$ \\
\hline 3. & Michika* & $1080.05\left(12^{\text {th }}\right)$ & $155,238\left(11^{\text {th }}\right)$ & $\begin{array}{l}\text { A very difficult mountainous area, already has the } \\
\text { highest number of wards }\end{array}$ \\
\hline 4. & Song & $4325.00\left(3^{\text {rd }}\right)$ & $195,188\left(4^{\text {th }}\right)$ & $\begin{array}{l}\text { Very large population and landmass, six traditional } \\
\text { administrative districts of many language groups, } \\
\text { some areas having strong feelings of being } \\
\text { oppressed and marginalized, difficult transportation, } \\
\text { and complex shape and landscape. }\end{array}$ \\
\hline 5. & Yola South & $719.00\left(19^{\text {th }}\right)$ & $196,197\left(3^{\text {rd }}\right)$ & $\begin{array}{l}\text { complex (sickle) shape within which transportation } \\
\text { is difficult. }\end{array}$ \\
\hline
\end{tabular}

*The LGA contested its 2006 Census figures as released by National Population Commission and won its case at the Federal High Court

For the federal constituency, the two additional seats should logically be apportioned to the current Fufore/Song (FC010/AD) and Mayo Belwa/Ganye/Jada/Toungo (FC011/AD) constituencies. The current Fufore/Song federal constituency should be split such that Fufore stands as a Federal Constituency and Girei from present Yola North/Yola South/Girei (FC016/AD) be detached and matched to Song to form a Federal Constituency while Yola North/Yola South remains as a metropolitan Federal Constituency. Similarly, the current FC011/ADshouldbe split such that Mayo Belwa/Jada and Ganye/Toungo each become a Federal Constituency (see Fig. 6).

To adjust and reduce the imbalance in the existing Senatorial Districts and achieve the true name of the districts: Northern, Southern and Central; a partial give and take may be necessary. Thus, to realize an equitable districts and fair representations at the Senate the two local government areas of Hong and Gombi in the northernmost part of the present Central district be detached and matched to the current Northern district while the two LGAs of Guyuk and Shelleng (a single federal constituency) be detached from the present Southern district and matched to the Central district; leaving seven LGAs to form the new Southern Senatorial District (see Fig. 7).

Table 4 Composition of the Proposed Senatorial Districts

\begin{tabular}{|c|c|c|c|c|c|c|}
\hline S/No. & $\begin{array}{l}\text { Senatorial } \\
\text { Districts }\end{array}$ & LGAs & $\begin{array}{l}\text { Total Landmass } \\
(\mathrm{Km} 2)\end{array}$ & Population & State Constituencies & $\begin{array}{l}\text { Federal } \\
\text { Constituencies }\end{array}$ \\
\hline 1. & Northern & $\begin{array}{l}\text { Gombi, Hong } \\
\text { Madagali, Maiha, } \\
\text { Michika, Mubi } \\
\text { North, Mubi South }\end{array}$ & $\begin{array}{l}9,290.11 \\
(23.55 \%)\end{array}$ & $\begin{array}{l}998,946 \\
(31.42 \%)\end{array}$ & $9(30 \%)$ & $3(30 \%)$ \\
\hline 2. & Southern & $\begin{array}{l}\text { Demsa, Ganye, } \\
\text { Jada, Lamurde, } \\
\text { Mayo Belwa, } \\
\text { Numan, Toungo }\end{array}$ & $\begin{array}{l}16,320 \\
(41.37 \%)\end{array}$ & $\begin{array}{l}924,577 \\
(29.08 \%)\end{array}$ & $11(36.66)$ & $4(40 \%)$ \\
\hline 3. & Central & $\begin{array}{l}\text { Fufore, Girei, } \\
\text { Guyuk, Shelleng, } \\
\text { Song, Yola north, } \\
\text { Yola South }\end{array}$ & $\begin{array}{l}13,840.83 \\
(35.08 \%)\end{array}$ & $\begin{array}{l}1,255,691 \\
(39.50 \%)\end{array}$ & $10(33.33)$ & $3(30 \%)$ \\
\hline
\end{tabular}

The relatively larger landmass of the Southern and higher population of the Central Senatorial districts is what could possibly be achieved without seriously distorting existing arrangements, and is within the generally acceptable deviations of $+/-15 \%$ while satisfying basic issues of contiguity, compactness and group 
harmony.Fears and apprehensions may be heightened among those whose interests were better understood/served within the existing order but on the balance of probabilities the proposed political space portrays no discernible infringement on political choices and may not radically alter behavioral outcomes.

\section{Conclusion}

In this paper we have argued that full participation in political governance entails fairness and justice in representation such that no region, community or group feels marginalized, deprived or willfully under represented. We, however, noted that the current electoral configuration in Adamawa State reveals clear imbalances that show some areas as over represented while others under represented. An equitable reapportionment of seats for the various levels of representation that, as far as possible, minimizes deviation from population quota and readjustments in the size of areas while maintaining administrative and cultural cohesiveness are proposed. It is expected that the proposed changes in the electoral arrangements will ease and enhance political involvement, representation and accountability over a more realistic political space.

\section{References}

[1]. Commonwealth, IFES and the United Nations (2003) Nigeria Electoral Review: Report to the Independent Electoral Commission (INEC) of the Federal Republic of Nigeria. www.aceproject.org/ero-en/regions/a./NG/ertreport/at_download/file, retrieved $07 / 10 / 2013$

[2]. Hant

C. $-(2012)$

Geographic

Information Processwww.wpsa.research.pdx.edu/meet/2012/honewicz.pdf retrieved 29/09/2013

[3]. Horn, M. (n.d.) GIS and the Geography of Politicswww.geosoed,ac,uk/wgisteach/gis book-abridge/file/ch.67.pdf retrieved $\underline{18 / 09 / 2013}$

[4]. Jega, A. (2013) Why we need to delineate constituencies again, www.theeagle.com.ng retrieved on 07/10/2013

[5]. Morrison, R. (n.d.) A Framework for Justice and Fairness, www.usbig.net/papers/017-RoyMorrison.doc retrieved 07/10/2013

[6]. Saunders, B. (2008) Democracy-as-fairness: Justice, Equal Chances and Lotteries, Erasmus Journal for Philosophy and Economics Vol.2 Issue. 1 pp. 154 - 158www.ejpe.org/pdf/2-1ts-3.pdf, retrieved 07/10/2013

[7]. Federal Government of Nigeria (2009) Federal Republic of Nigeria Official Gazette No.2 Vol.96: Legal Notice on Publication of 2006 Census Final Result. www.scribd.com/.../Legal_Notice_on_pub... Retrieved 07/10/2013

[8]. Crocker, R. (2012) Congressional Redistricting: An Overview. Congressional Research Services, Report for Congress. www.crs.gov, (www.fas.org/sgp/crs/misc/R42831.pdf) retrieved on 5/10/2013

[9]. Musa. A. A. \&Tukur A. L.. (2008) Measuring Land Cover Indices of Adamawa State Using GIS Techniques. Journal of the Environment. Vol 2. No 2.

[10]. Linton, N. (2013) The Road to Better Redistricting: Empirical Analysis and State-Based Reform to Counter Partisan Gerrymandering. Ohio State Law Journal Vol. 73:4 www.moritzlaw.osu.edu/.../73.4.Litton.pdf.Retrieved on 5/10/2013

[11]. Rehfeld, A. (2009) Representation Rethought: On Trustees, Delegates, and Gyroscopes in the Study of political Representation and Democracy, American Political Science Review Vol.103, No.2 doi: 1017/S0003055409090261 


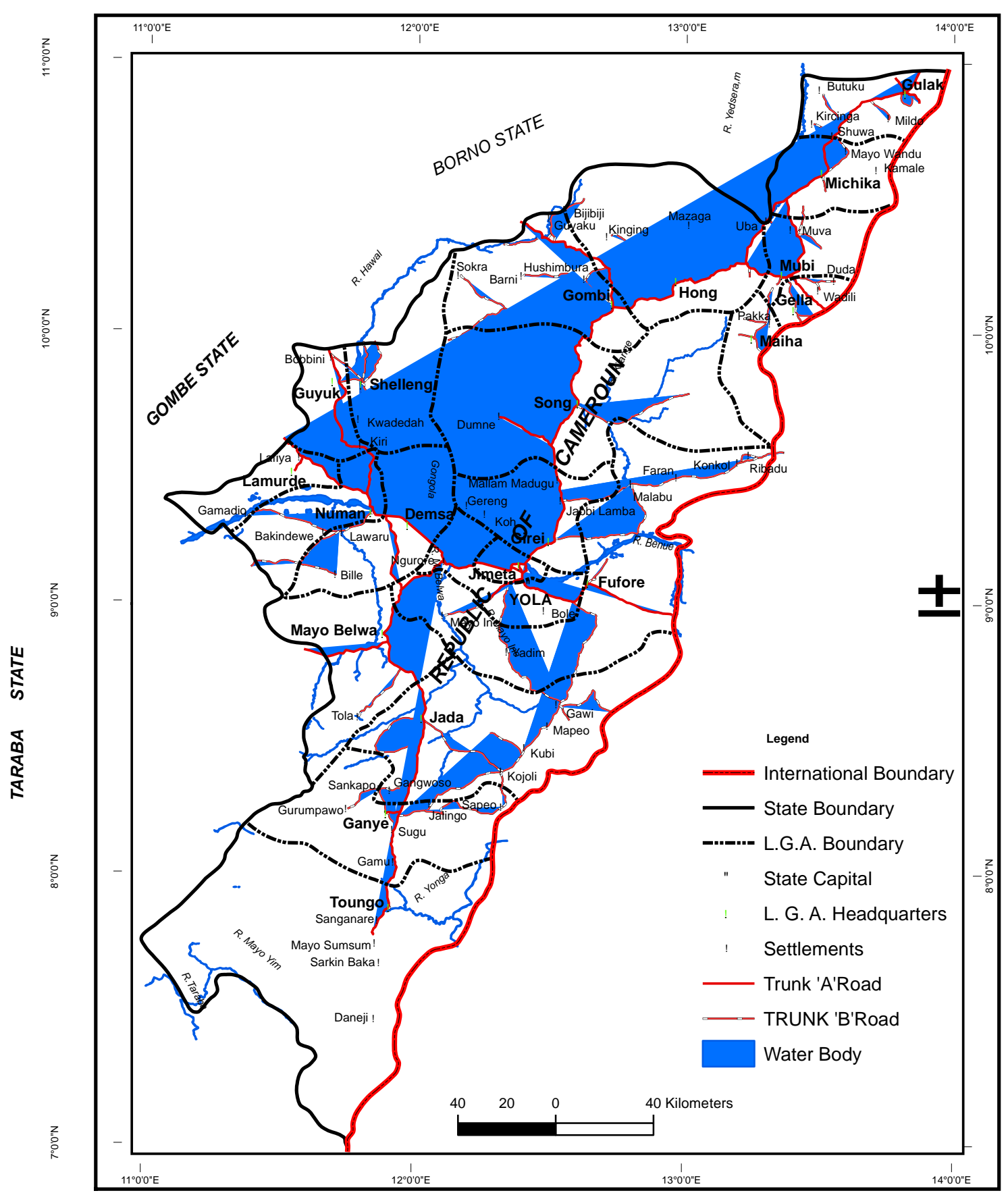

Fig. 1: Adamawa State 


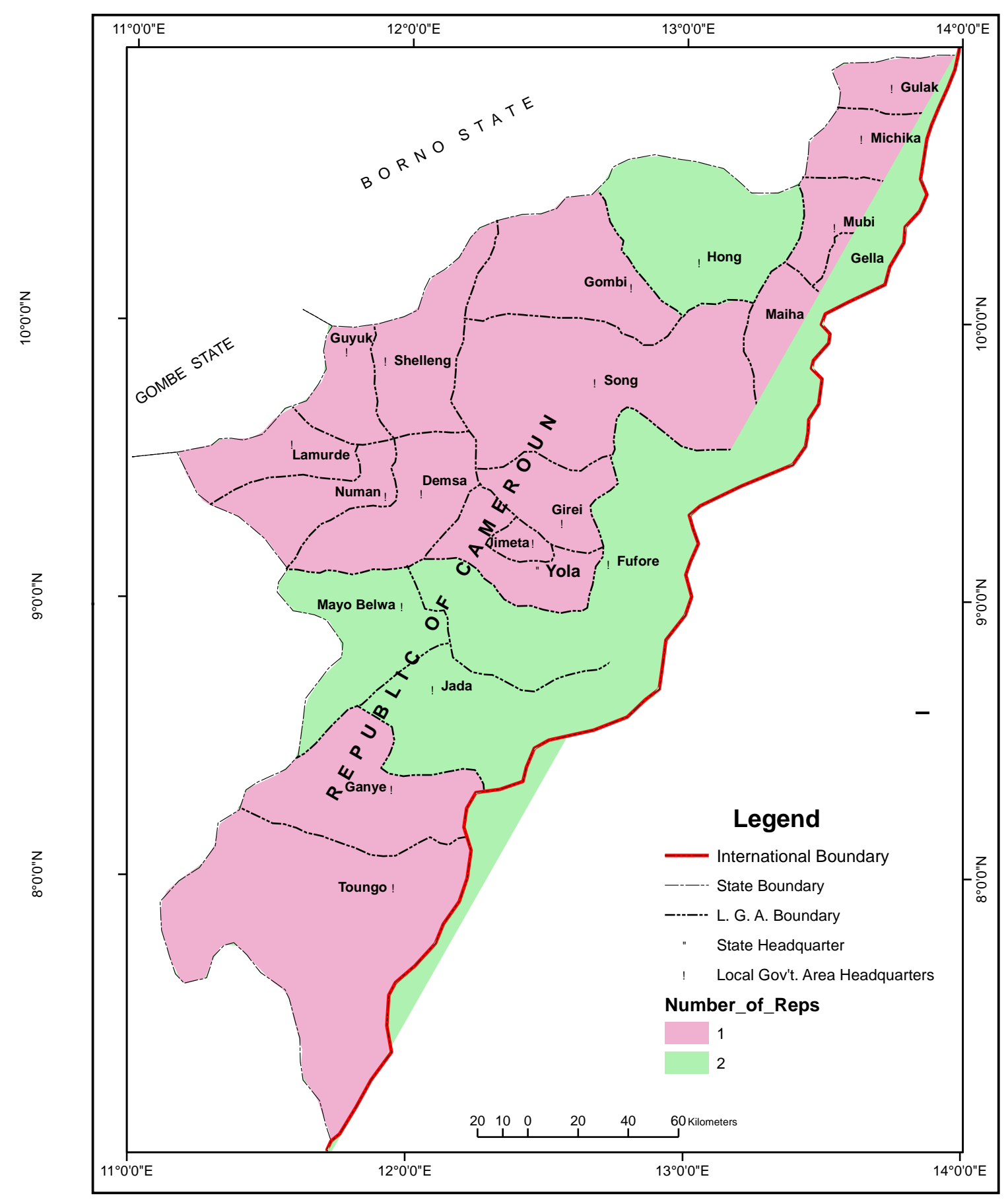

Fig. 2: Existing Number of State Constituencies in each Local Government Area. 


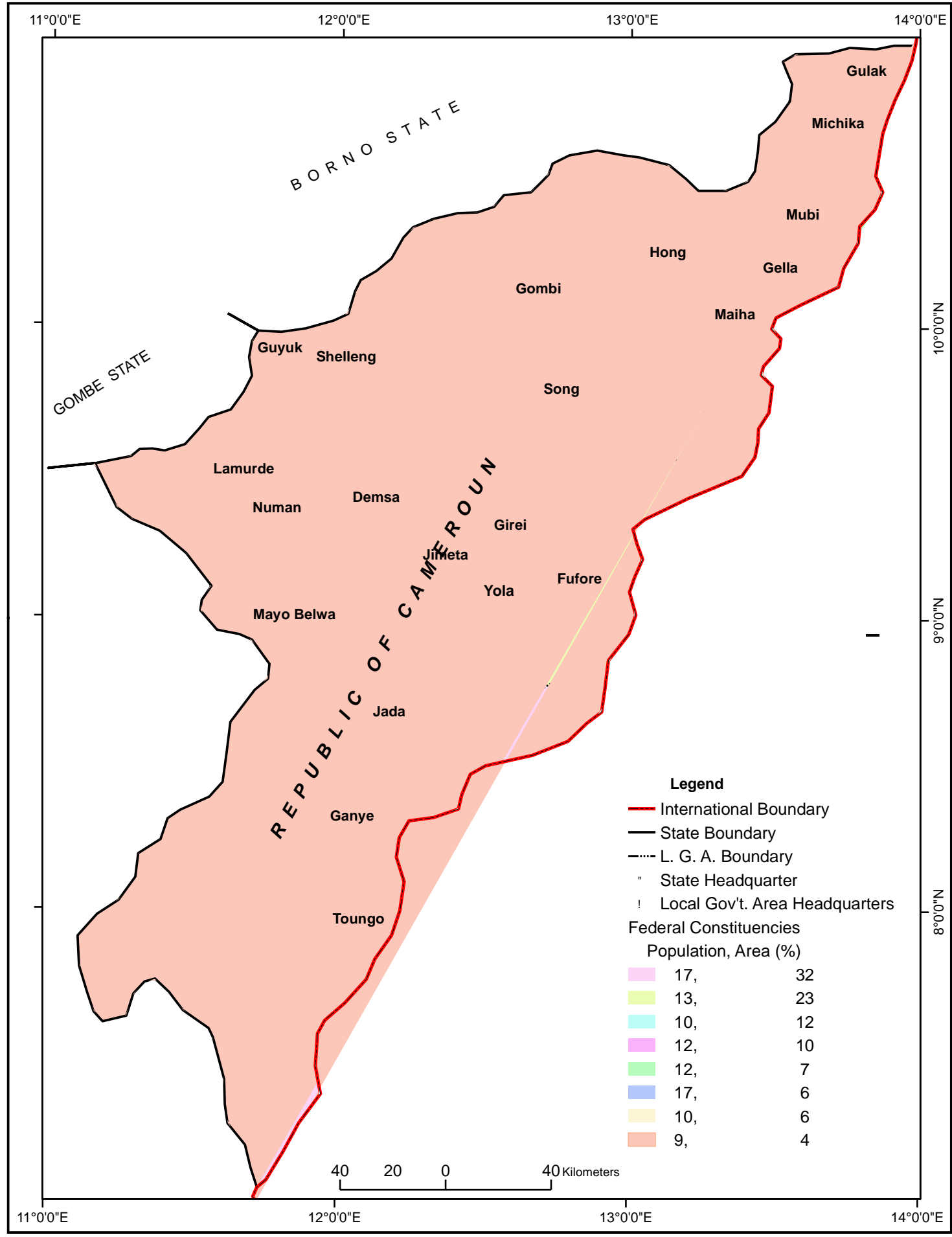

Fig. 3: Existing Eight Federal Constituencies 


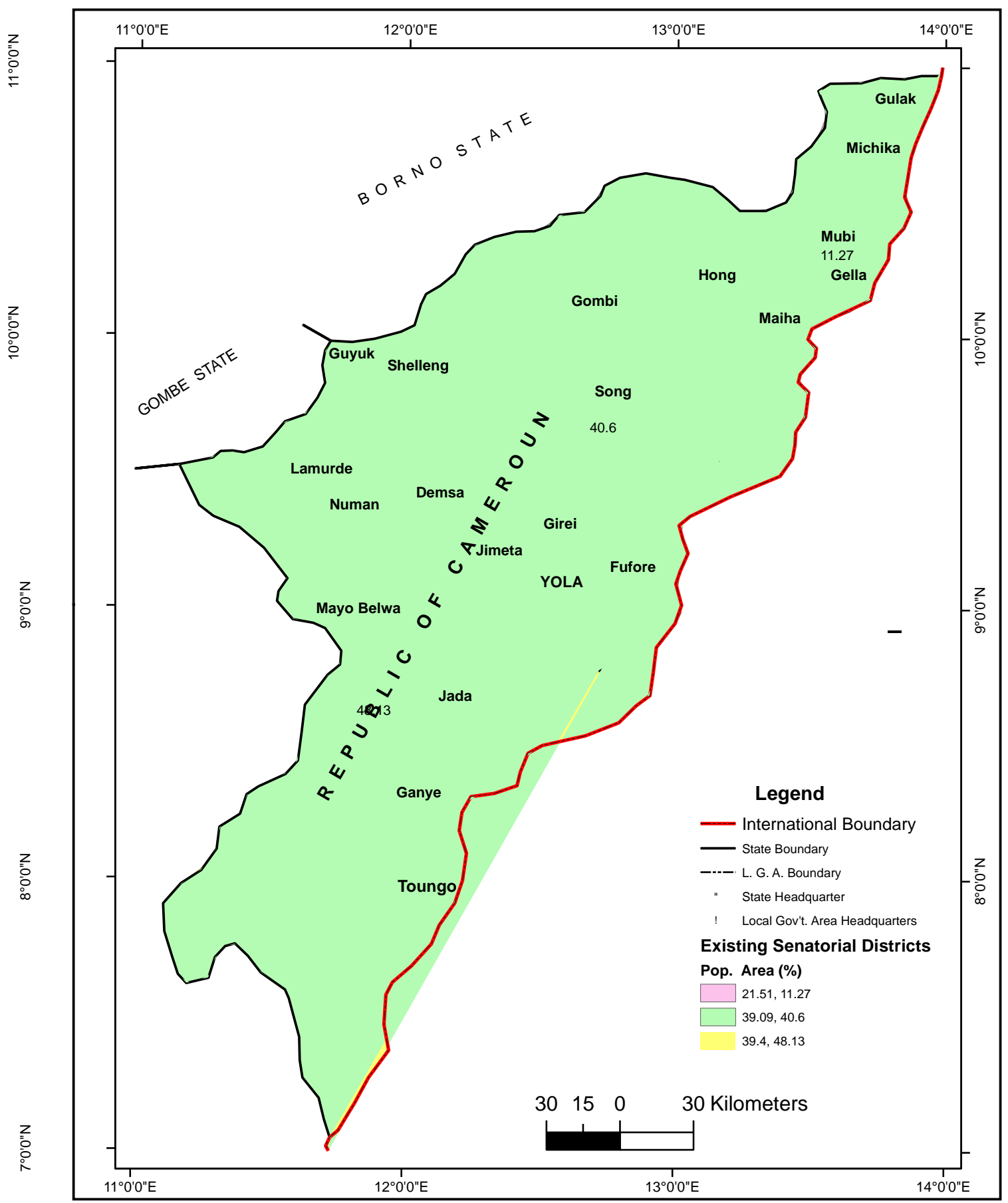

Fig. 4: Existing Senatorial Districts 


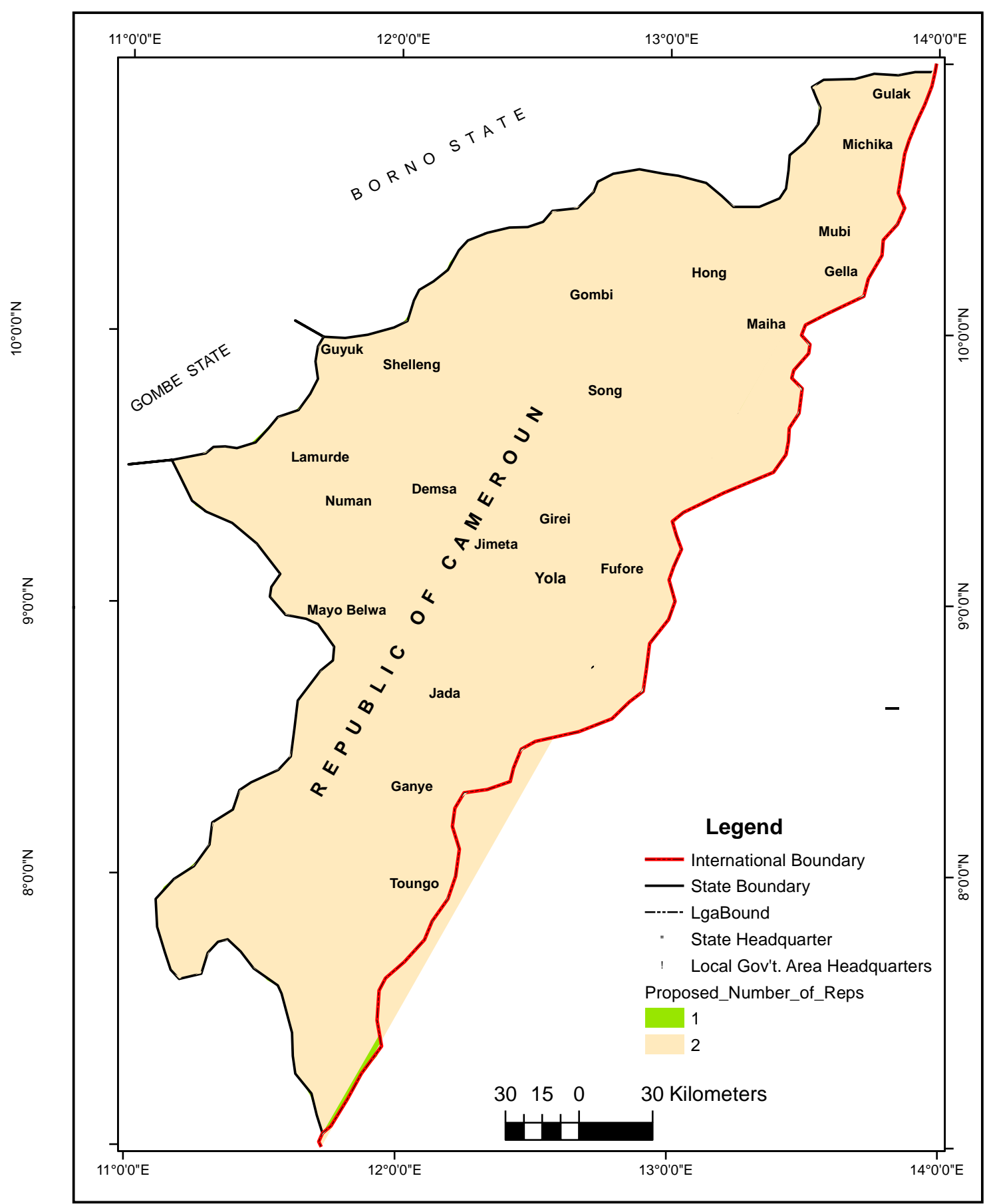

Fig. 5: Proposed Number of State Constituencies in Each Local Government Area 


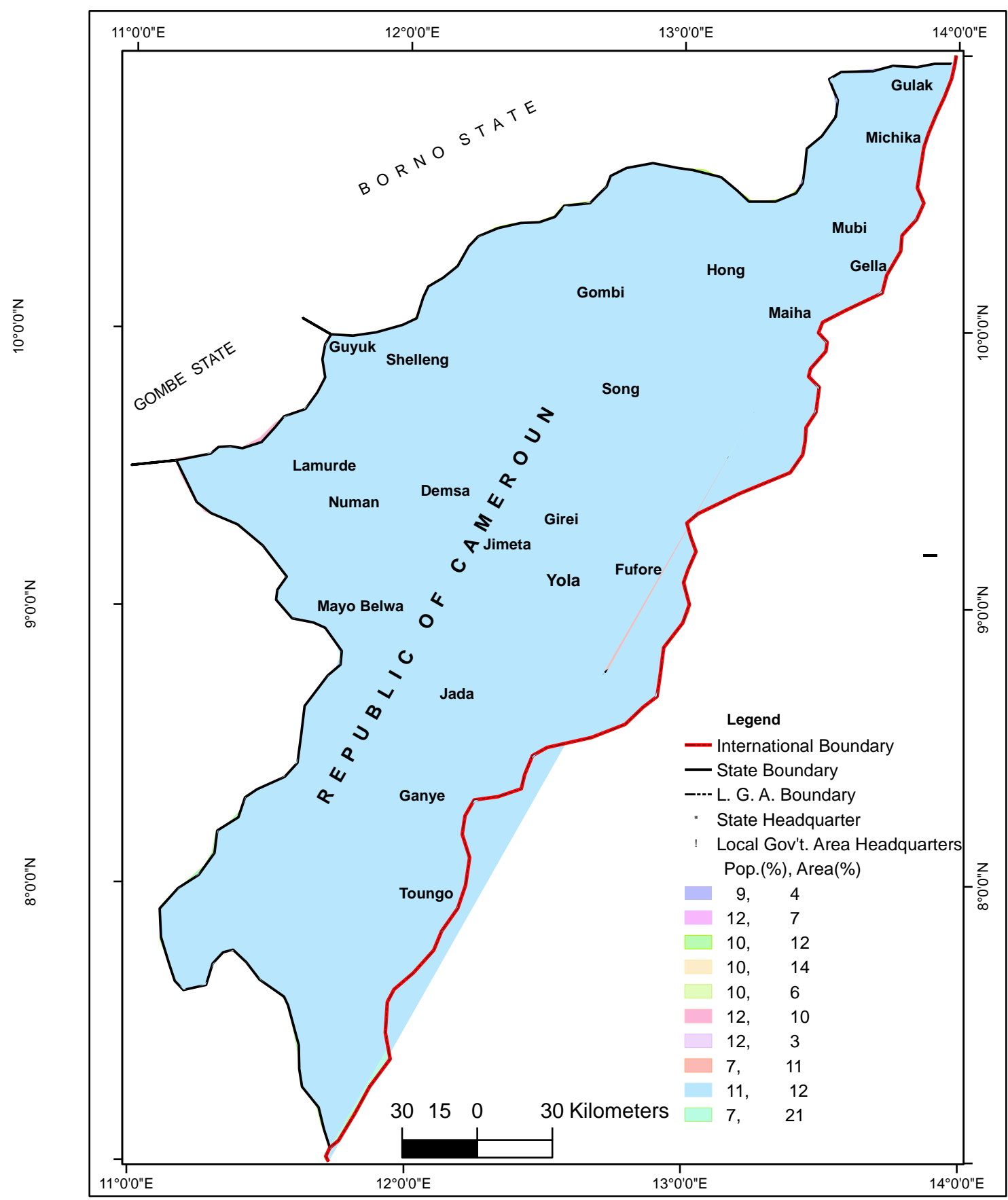

Fig. 6: Proposed Ten Federal Constituencies 


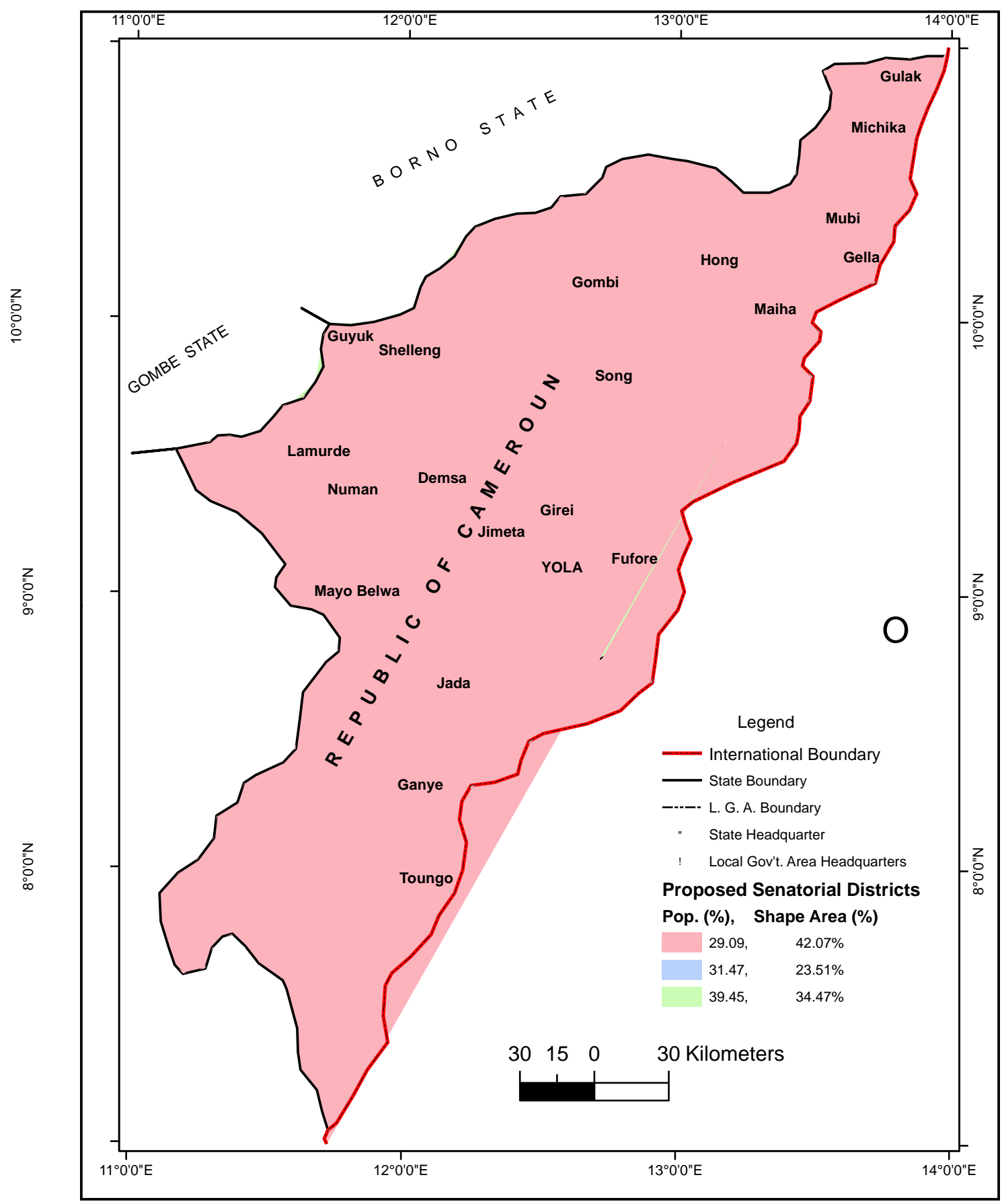

Fig. 7: Proposed Senatorial Districts 